\title{
Tissue Injury Regulates Serotonin 1D Receptor Expression: Implications for the Control of Migraine and Inflammatory Pain
}

\author{
Andrew H. Ahn ${ }^{1,2}$ and Allan I. Basbaum ${ }^{2,3,4}$ \\ Departments of ${ }^{1}$ Neurology, ${ }^{2}$ Anatomy, and ${ }^{3}$ Physiology, and ${ }^{4}$ The W. M. Keck Foundation Center for Integrative Neuroscience, University of California, \\ San Francisco, San Francisco, California 94158
}

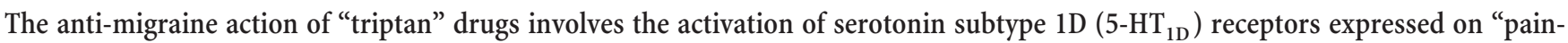
responsive" trigeminal primary afferents. In the central terminals of these nociceptors, the receptor is concentrated on peptidergic dense core vesicles (DCVs) and is notably absent from the plasma membrane. Based on this arrangement, we hypothesized that in the resting state the receptor is not available for binding by a triptan, but that noxious stimulation of these afferents could trigger vesicular release of DCVs, thus externalizing the receptor. Here we report that within $5 \mathrm{~min}$ of an acute mechanical stimulus to the hindpaw of the rat, there is a significant increase of $5-\mathrm{HT}_{1 \mathrm{D}}$-immunoreactivity (IR) in the ipsilateral dorsal horn of the spinal cord. We suggest that these rapid immunohistochemical changes reflect redistribution of sequestered receptor to the plasma membrane, where it is more readily detected. We also observed divergent changes in $5-\mathrm{HT}_{1 \mathrm{D}}$-IR in inflammatory and nerve-injury models of persistent pain, occurring at least in part through the regulation of $5-\mathrm{HT}_{1 \mathrm{D}}$-receptor gene expression. Finally, we found that $5-\mathrm{HT}_{1 \mathrm{D}}-\mathrm{IR}_{\mathrm{R}}$ is unchanged in the spinal cord dorsal horn of mice with a deletion of the gene encoding the neuropeptide substance P. This result differs from that reported for the $\partial$-opioid receptor, which is also sorted to DCVs, but is greatly reduced in preprotachykinin mutant mice. We suggest that a "pain"-triggered regulation of $5-\mathrm{HT}_{1 \mathrm{D}}$-receptor expression underlies the effectiveness of triptans for the treatment of migraine. Moreover, the widespread expression of $5-\mathrm{HT}_{1 \mathrm{D}}$ receptor in somatic nociceptive afferents suggests that triptans could, in certain circumstances, treat pain in nontrigeminal regions of the body.
\end{abstract}

Key words: migraine; pain; serotonin receptor; opioid receptor; substance P; calcitonin-gene related peptide; trigeminal; dorsal root ganglion; spinal cord

\section{Introduction}

Migraine is a common disabling disorder whose neurobiological mechanism is poorly understood, but is likely to involve abnormal activation of trigeminal afferents of the dura and cerebral blood vessels, sensitization of neurons in the trigeminal nucleus caudalis, and dysregulation of pain-control regions of the brain (Burstein, 2001; Goadsby et al., 2002). Although the relative contribution of peripheral and CNS mechanisms is not established, the pathophysiology may include local neurogenic inflammation of the meninges (Markowitz et al., 1987), activation of intracranial afferents (Strassman et al., 1996), and the release of the neuropeptide calcitonin gene-related peptide (CGRP) from these afferents (Zagami et al., 1990), facilitating increased noxious

This work was supported by a Postdoctoral Fellowship from the Howard Hughes Medical Institute, a Research Award from the International Headache Society, and National Institutes of Health-National Institute of Neurological Disorders and Stroke Grants NS 47113 (A.H.A.), NS 14627, NS 48499, and NS 21445 (A.I.B.). We thank Dr. Howard Fields for comments and discussion on the manuscript and Ms. Erin Martin for excellent technical assistance.

Correspondence should be addressed to Andrew H. Ahn, University of California, San Francisco, Box 2722, 1550 Fourth Street, San Francisco, CA 94158-2722. E-mail: andrew.ahn@ucsf.edu.

DOI:10.1523/JNEUROSCI.1989-06.2006

Copyright $\odot 2006$ Society for Neuroscience $\quad$ 0270-6474/06/268332-07\$15.00/0 stimulus-evoked activity in the trigeminal nucleus caudalis (Storer et al., 2004).

Triptans are serotonin (5-HT) receptor selective agonists with activity at $5-\mathrm{HT}_{1 \mathrm{~B}}, 5-\mathrm{HT}_{1 \mathrm{D}}$, and $5-\mathrm{HT}_{1 \mathrm{~F}}$ receptors, and have well established utility in the treatment of migraine pain. In the periphery, triptans prevent or block neurogenic inflammation (Moskowitz, 1993; Bolay et al., 2002), at least in part, by inhibiting the release of substance P (SP) and CGRP from peptidergic afferents (Buzzi et al., 1991). There is also evidence for a central action of triptans (Kaube et al., 1993; Shepheard et al., 1995), including presynaptic regulation of neurotransmitter release from the central terminals of primary afferents in the trigeminal nucleus caudalis (Jennings et al., 2004; Levy et al., 2004), postsynaptic regulation of the responses of caudalis neurons to glutamate or an NMDA agonist (Goadsby et al., 2001), and activation of triptan receptors expressed by pain-modulatory neurons in the periaqueductal gray (Bartsch et al., 2004).

The remarkable clinical specificity of the triptans for migraine and cluster headache and their lack of effect in other pain disorders pose several questions concerning their mechanism of action on primary afferents (Ahn and Basbaum, 2005). Although triptans appear to selectively act on pain associated with the trigeminal region, we reported recently that $5-\mathrm{HT}_{1 \mathrm{D}}$ receptors are 
present in a similar subpopulation of trigeminal and dorsal root ganglia neurons and in the central terminals of these afferents (Potrebic et al., 2003). Because $5-\mathrm{HT}_{1 \mathrm{D}}$ receptors are not restricted to cranial afferents, it is unclear why triptans have selective actions for migraine pain, and conversely, why triptans do not modulate pain in other regions of the body. We also observed that the receptor is concentrated exclusively within the dense core vesicles (DCVs) of peptidergic terminals. We found no immunostaining on the plasma membrane, where triptans would have direct access to the receptor, so we hypothesized that triptans could stimulate these receptors only after noxious stimulation had triggered the exocytosis and delivery of DCV-bound 5- $\mathrm{HT}_{1 \mathrm{D}}$ receptor to the plasma membrane.

Here we present immunohistochemical evidence that noxious stimulation indeed induces a rapid increase in $5-\mathrm{HT}_{1 \mathrm{D}}$ receptor in the spinal cord dorsal horn, which likely reflects a redistribution of the receptor at the primary afferent terminal. We also provide evidence for the differential regulation of the $5-\mathrm{HT}_{1 \mathrm{D}}$ receptor in tissue and nerve injury models of persistent pain, which may be relevant to the utility of triptans in the treatment of nonmigrainous pain.

\section{Materials and Methods}

Receptor activation in models of pain

Male Sprague Dawley rats weighing 175-250 g were used in accordance with protocols approved by the Institutional Animal Care and Use Committee.

Noxious mechanical stimulation. Rats were anesthetized under 1.5-2\% isoflurane with $2 \mathrm{~L} / \mathrm{min}$ flow of oxygen until blink and withdrawal reflexes were suppressed. The mechanical pinch stimulus of the left hindpaw was made by 2 min of pressure across the left hindpaw with a loose hemostat; this stimulus evokes the release of substance P from the nociceptors (McCarson and Goldstein, 1991) and internalization of the neurokinin 1 (NK-1) receptor in dorsal horn neurons (Abbadie et al., 1997). The rats were maintained under inhalation anesthesia, until they received a terminal dose of pentobarbital $(100 \mathrm{mg} / \mathrm{kg})$ and were perfused as described below for immunohistochemistry. Six to nine animals were used for each time point.

Complete Freund's adjuvant-induced inflammation. To induce tissue inflammation, we injected $75 \mu \mathrm{l}$ of a $50 \%$ emulsion of complete Freund's adjuvant (CFA) (Sigma, Saint Louis, MO), mixed in saline, intradermally into the left hindpaw using a 30 -guage needle while animals were anesthetized under $2 \%$ isoflurane with $2 \mathrm{~L} / \mathrm{min}$ flow of $\mathrm{O}_{2}$. After recovery from anesthesia, the animals were returned to their home cage. From 1-7 $\mathrm{d}$ later, the animals were anesthetized and perfused for immunohistochemistry or RNA analysis. Three to six animals were used for each time point.

Sciatic nerve section. In another group of rats, we transected the sciatic nerve under the same inhalation anesthesia protocol. After $21 \mathrm{~d}$, three $(n=3)$ animals were anesthetized and perfused for immunohistochemistry and for RNA analysis.

\section{Immunohistochemistry}

Tissue preparation. Animals were overdosed with sodium pentobarbital $(100 \mathrm{mg} / \mathrm{kg})$ and perfused with heparinized saline followed by fixation with $10 \%$ formalin in $0.1 \mathrm{~m}$ sodium phosphate buffer, $\mathrm{pH}$ 7.4. The spinal cords were collected, postfixed for $4 \mathrm{~h}$, and cryoprotected for $2 \mathrm{~d}$ in $30 \%$ sucrose in $0.1 \mathrm{~m}$ sodium phosphate buffer, $\mathrm{pH}$ 7.4. For immunostaining, we cut $50 \mu \mathrm{m}$ transverse frozen sections through the lumbar enlargement. In the 5 min postpinch series, we processed 20 alternate sections from the L4 through the L6 segments. For the longer time points, we only processed sections through the L5 to L6 segments, in which changes in activation of $5-\mathrm{HT}_{1 \mathrm{D}}$ receptor predominated. The referred region of lumbar spinal cord from CFA treated (L5-L6) and sciatic nerve cut (L4L5) animals were examined in a similar manner.

HRP-DAB immunostaining procedure. Before exposure to antibody, free-floating sections were preincubated for $1 \mathrm{~h}$ at room temperature
(RT) in PBS with $0.3 \%$ Triton X-100 (PBST) and 10\% normal goat serum (NGS). Primary and secondary antisera were diluted in PBST with $2 \%$ NGS (2\% NGST). Tissue was incubated overnight at room temperature in rabbit anti-5-HT $\mathrm{HD}_{1 \mathrm{D}}$ antibody (1:100,000). This affinity-purified antibody, which has been characterized and described in detail previously (Potrebic et al., 2003), was raised against an oligopeptide corresponding to a subtype-specific region of $5-\mathrm{HT}_{1 \mathrm{D}}$, predicted to be in an intracellular loop of the receptor. Sections were then washed three times in $2 \%$ NGST for $10 \mathrm{~min}$ each and incubated for $1 \mathrm{~h}$ at room temperature with biotinylated goat anti-rabbit antibody (Vector Laboratories, Burlingame, CA) in 2\% NGST, and washed three times in PBST for 10 min each at RT. To localize the secondary antibody, we used an avidin-biotin HRP protocol with an $\mathrm{ABC}$ kit (Vector Laboratories), glucose oxidase, and nickelenhanced 3,-3'diaminobenzidine (DAB; Sigma) as chromogen. Sections were then mounted on gelatin-coated glass slides and coverslipped under DPX mounting media (EM Sciences, Fort Washington, PA).

Fluorescence immunohistochemistry. Tissue was fixed and cryoprotected as above. Spinal cord and DRG tissues were cut at $14 \mu \mathrm{m}$ and stained essentially as described previously (Potrebic et al., 2003). The antibodies were used in the following dilutions: rabbit anti-5- $\mathrm{HT}_{1 \mathrm{D}}$ at 1:40,000; guinea pig anti-substance $\mathrm{P}$ at 1:6000; mouse monoclonal antineurofilament of $200 \mathrm{kDa}$ (NF200, clone N52/RT97; Sigma) at 1:1200; mouse monoclonal anti-CGRP (\#4901; kindly provided by Dr. Catia Sternini, University of California, Los Angeles, CA) at 1:1250 (Wong et al., 1993); rabbit anti- $\delta$ opioid receptor (DOR; \#10271; Abcam, Cambridge, MA) at 1:2000.

\section{Light microscopy and image analysis}

We photographed sections with a Nikon (Tokyo, Japan) Eclipse microscope with an attached Spot or Zeiss (Oberkochen, Germany) digital camera. We analyzed $8-10$ sections from each animal, from files in which the side of the lesion was blinded to the observer. We quantified the staining of $5-\mathrm{HT}_{1 \mathrm{D}}-\mathrm{IR}$ with National Institutes of Health image analysis software (Image J for Macintosh OS X), by outlining the region of interest in the medial dorsal horn symmetrically on either side of the spinal cord, and then obtaining the mean optical density of the immunohistochemical reaction product. Because we did not obtain a pixel count, no threshold cutoff was made. Rather, to correct for local illumination effects and variation in background staining, we subtracted the mean optical density of the nearby deep dorsal horn on each side, where there was no reaction product. The staining density is expressed as a ratio of the ipsilateral over the contralateral side. All ratios are represented as the mean of the average ratios determined for each animal \pm SEM. A Student's $t$ test between the ipsilateral and contralateral sides was applied as a test of significance $(p<0.05)$.

\section{RNA isolation and real-time PCR analysis}

To prepare RNA for analysis, we collected individual lumbar L5 DRG's after intracardiac perfusion with $100 \mathrm{cc}$ saline, followed by $100 \mathrm{cc}$ RNAlater (Ambion, Austin, TX). The DRG's were incubated at $4^{\circ} \mathrm{C}$ overnight in RNAlater and then stored at $-20^{\circ} \mathrm{C}$. For RNA isolation, the RNAlater was aspirated and the DRGs homogenized in Trizol (Invitrogen, Carlsbad, CA) with individual disposable microcentrifuge pestles, and the isolation procedure was performed per the manufacturer's recommendations. To remove contaminating genomic DNA, the RNA was purified in RNeasy mini-columns (Qiagen, Valencia, CA) per the manufacturer's recommendations. The RNA was quantified by Ribogreen fluorescence against a standard curve, and the absence of genomic DNA was confirmed by Picogreen fluorescence (Invitrogen). The threshold for detection was $<10 \mathrm{pg} / \mu \mathrm{l}$. Three rats were used for each time point, and $\sim 1.0$ $\mu \mathrm{g}$ of total RNA was isolated from each ganglion. The RNA sample from each ipsilateral ganglion was paired to the contralateral ganglion for comparison of relative expression.

For cDNA synthesis, a parallel set of reactions using $1.0 \mu \mathrm{g}$ of RNA each was reverse-transcribed with oligo-dT primers and Superscript II reverse transcriptase (Invitrogen), corresponding to a $1.0 \mu \mathrm{g}$ equivalent of cDNA. After the appropriate dilution curves, we amplified $20 \mathrm{ng}$ of cDNA in a TaqMan assay using Amplitaq-Gold reagents (Applied Biosystems, Foster City, CA) in an Applied Biosystems Real-Time PCR sys- 


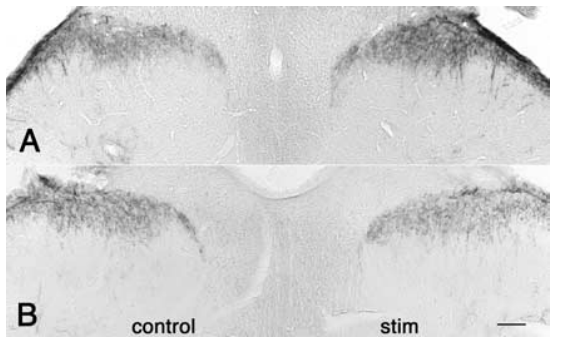

Figure 1. Dynamic regulation of $5-\mathrm{HT}_{10}-\mathrm{IR}$ in the dorsal horn of the spinal cord after acute mechanical stimulation. $\mathrm{L} 5$ lumbar spinal cord staining for $5-\mathrm{HT}_{10}-\mathrm{IR}$ in an animal perfused 5 $\min (\boldsymbol{A})$ and $30 \mathrm{~min}(\boldsymbol{B})$ after mechanical pinch shows increased $5-\mathrm{HT}_{10}-\mathrm{IR}$ at 5 min and reduced staining at $30 \mathrm{~min}$ on the stimulated (right) side, compared with the contralateral unstimulated side (control). Scale bar, $100 \mu \mathrm{m}$.

tem. The reactions were all performed in triplicate, and the mouse glyceraldehyde-3-phosphate dehydrogenase (GAPDH) primer set (Applied Biosystems) was used as an endogenous control to normalize the cDNA templates. The $5-\mathrm{HT}_{1 \mathrm{D}}$ mRNA was detected with flanking primers 5'-CCCGGAGTCGAATCCTGAA-3'， 5'-TGATAAGCTGTGCTGTGGTGAA-3', and probe 5'6-FAM-CTATCTTGGTCATGCCCATCAGC-BHQ-3' labeled with 6-FAM (6 carboxy fluorescein-aminohexyl amidite) and BHQ (black hole quencher; Biosearch Technologies, Novato, CA).

Dilution curves were performed on cDNA from pooled DRG or trigeminal ganglion samples in a separate series of reactions to show that this primer set amplified with an efficiency of $97 \%$. We determined the threshold values and performed relative quantification calculations using Applied Biosystems software. Ratios of the individual DRGs compared with their contralateral controls are shown as means \pm SEM. A Student's $t$ test between the ipsilateral and contralateral sides was applied as a test of significance $(p<0.05)$

\section{Results}

\section{Acute activation by mechanical pinch}

Because noxious mechanical stimulation (pinch) efficiently stimulates substance P release (McCarson and Goldstein, 1991) and postsynaptic NK-1 receptor internalization within 5 min (Abbadie et al., 1997), we chose this time point for acute activation. In animals perfused $5 \mathrm{~min}$ after pinch, we observed a significant increase in $5-\mathrm{HT}_{1 \mathrm{D}}-\mathrm{IR}$ in the medial half of the ipsilateral L5 spinal cord dorsal horn, where afferent terminals from the hindpaw are most densely concentrated (Fig. $1 A$ ). To normalize the fixation and immunohistochemical reaction conditions, we compared the staining on the stimulated side to the untreated contralateral side. In addition to increased density of reaction

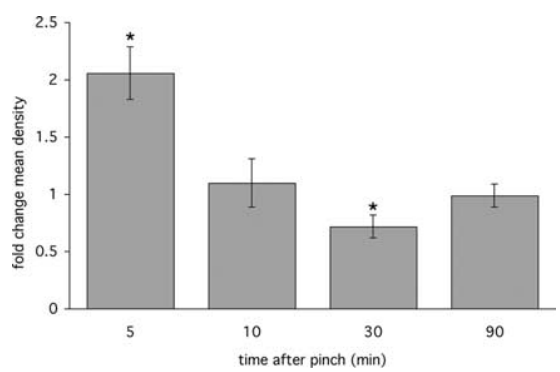

Figure 2. Quantitative analysis of $\mathrm{L} 5$ lumbar spinal cord $5-\mathrm{HT}_{10}-\mathrm{IR}$ in a time series of animals after pinch stimulus of the hindpaw shows the rapid increase of staining at $5 \mathrm{~min}$ followed by a reduction in staining at $30 \mathrm{~min}$, and a normalization at $90 \mathrm{~min}$. Fold changes in mean optical density are represented as a ratio of the mean optical density in the medial half of the ipsilateral over the contralateral dorsal horn $\left({ }^{*} p<0.05\right)$. The levels of $5-\mathrm{HT}_{10}-\mathrm{IR}$ at other spinal cord segments do not differ on the two sides of the cord; the same is true for sections of the L5 segment from untreated animals.

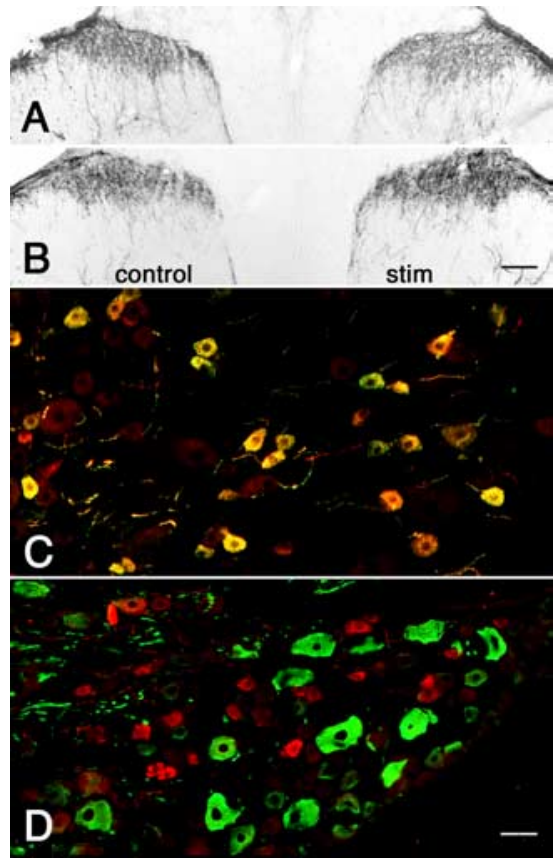

Figure 3. Unilateral sensitization of the hindpaw by the inflammatory agent (FA shows dynamic changes in $5-\mathrm{HT}_{1 \mathrm{D}}-\mathrm{IR}$ in the ipsilateral dorsal horn. $\boldsymbol{A}$, After $3 \mathrm{~d}$, the ipsilateral (right) side of the spinal cord shows reduced $5-\mathrm{HT}_{1 \mathrm{D}}-\mathrm{IR}$ compared with the untreated side (control). $\boldsymbol{B}$ After $7 \mathrm{~d}$, the level of $5-\mathrm{HT}_{1 \mathrm{D}}-\mathrm{IR}$ is increased ipsilateral to the stimulus. $\boldsymbol{C}$, The $\mathrm{L} 5$ dorsal root ganglia ipsilateral to CFA stimulation at $7 \mathrm{~d}$ continues to show significant colocalization of 5- $\mathrm{HT}_{1 \mathrm{D}}-\mathrm{IR}$ (red) and substance $\mathrm{P}$ (green), whereas $(\boldsymbol{D}) 5-\mathrm{HT}_{10}-\mathrm{IR}$ neurons (red) are present in only a small minority of myelinated afferents that immunostain for NF200 (green). Scale bars: (in $\boldsymbol{B}$ ) $\boldsymbol{A}, \boldsymbol{B}, 100 \mu \mathrm{m}$; (in $\boldsymbol{D}) \boldsymbol{C}, \boldsymbol{D}, 20 \mu \mathrm{m}$.

product, we noted that the staining pattern in the ipsilateral dorsal horn was more granular and punctate (Fig. 1A). Although we observed changes at the L4 segment of the cord, they were not statistically significant. Figure 2 summarizes the time course of these changes. When tissue was analyzed $30 \mathrm{~min}$ after the pinch stimulus, we observed a significant decrease of $5-\mathrm{HT}_{1 \mathrm{D}}$-IR compared with the contralateral side (Fig. $1 B$ ). At 90 min after the pinch stimulus there were no longer differences in $5-\mathrm{HT}_{1 \mathrm{D}}-\mathrm{IR}$ between the two sides.

\section{$5-\mathrm{HT}_{1 \mathrm{D}}$ receptor in the setting of persistent inflammation}

We next asked whether persistent noxious stimulation with intraplantar CFA could also induce changes in $5-\mathrm{HT}_{1 \mathrm{D}}$-receptor expression. This model involves inflammation and pain-related behaviors that peak at $3 \mathrm{~d}$ postinjection, followed by a slow decline in sensitization over the following 10-14 d (Iadarola et al.,

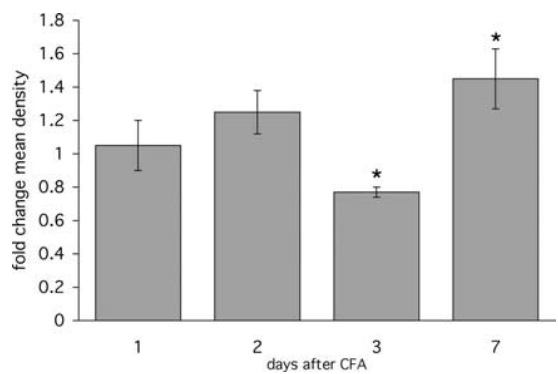

Figure 4. Time course of $5-\mathrm{HT}_{1 \mathrm{D}}-\mathrm{IR}$ after unilateral CFA-induced inflammation. Ipsilateral hindpaw inflammation produces complex changes in $5-\mathrm{HT}_{10}-\mathrm{IR}$ in the medial half of the $\mathrm{L} 5$ spinal cord dorsal horn. Levels of $5-\mathrm{HT}_{1 \mathrm{D}}-\mathrm{IR}$ are reduced at $3 \mathrm{~d}$ post-CFA, but rise significantly compared with the contralateral side at day $7 .{ }^{*} p<0.05$. Error bars are SEM. 


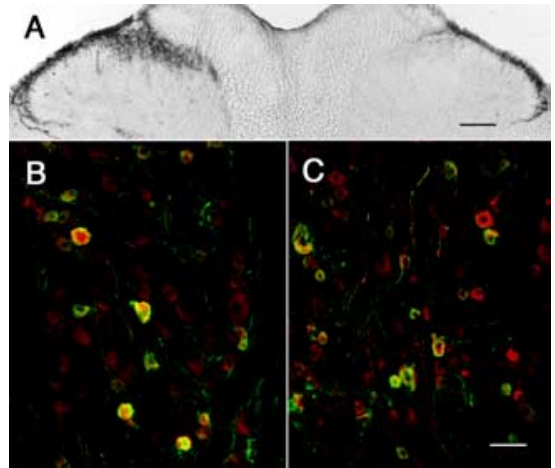

Figure 5. Differential DRG and spinal cord expression of $5-\mathrm{HT}_{10}-\mathrm{IR}$ after peripheral nerve injury. $\boldsymbol{A}, 5-\mathrm{HT}_{10}-\mathrm{IR}$ in the dorsal horn $21 \mathrm{~d}$ after complete sciatic nerve transection shows significant reduction of immunoreactivity in the medial portion of the dorsal horn ipsilateral (right) to the injury. Double labeling of $\mathrm{L} 5$ dorsal root ganglia for $5-\mathrm{HT}_{10}$ (red) and CGRP (green) contralateral $(\boldsymbol{B})$ and ipsilateral $(\boldsymbol{C})$ to the sciatic nerve transection shows the persistence of receptor expression in peptidergic cell bodies despite its dramatic reduction in their central terminals. Scale bars: $\boldsymbol{A}, 100 \mu \mathrm{m}$; (in $\boldsymbol{C}) \boldsymbol{B}, \boldsymbol{C}, 20 \mu \mathrm{m}$.

1988). We observed a complex progression of $5-\mathrm{HT}_{1 \mathrm{D}}$-IR in the $7 \mathrm{~d}$ postinjection (Fig. 3), which is quantitatively summarized in Figure 4. During the first $2 \mathrm{~d}$ postinjection, there was a variable degree of expression, both up or down within individual animals, that was not significantly different from the contralateral side. On the third postinjection day, $5-\mathrm{HT}_{1 \mathrm{D}}-\mathrm{IR}$ declined significantly compared with the contralateral dorsal horn (Fig. $3 A$ ). At $7 \mathrm{~d}$ after injection, when paw edema and nociceptive thresholds begin to normalize, we observed a significant increase in $5-\mathrm{HT}_{1 \mathrm{D}}-\mathrm{IR}$ (Fig. 3B).

The increased 5- $\mathrm{HT}_{1 \mathrm{D}}-\mathrm{IR} 7 \mathrm{~d}$ after CFA could be attributable to either even greater levels of receptor expression in peptidergic afferents, or alternatively, to new synthesis in a separate class of afferents. To address this question we used double-label immunohistochemistry to determine what proportion of $5-\mathrm{HT}_{1 \mathrm{D}}-\mathrm{IR}$ DRG neurons also expressed the neuropeptide substance P (Fig. $3 C)$. We found that $94 \%$ of the ipsilateral $5-\mathrm{HT}_{1 \mathrm{D}}$-immunoreactive L5 afferents were also SP immunoreactive, compared with $92 \%$ of the contralateral afferents. To address the possibility that $5-\mathrm{HT}_{1 \mathrm{D}}-\mathrm{IR}$ neurons are newly synthesized by myelinated afferents, we used double-label immunohistochemistry for NF200. In fact, we found that only $6 \%$ of the $5-\mathrm{HT}_{1 \mathrm{D}}$-IR DRG neurons expressed N52 ipsilateral to the stimulus, which was comparable to that on the contralateral side (10\%) (Fig. 3D). These proportions are comparable with those we reported previously in normal untreated animals (Potrebic et al., 2003).

\section{$5-\mathrm{HT}_{1 \mathrm{D}}$ receptor in the setting of nerve injury}

To assess the consequences of nerve injury on $5-\mathrm{HT}_{1 \mathrm{D}}$ receptor expression, we evaluated the effects of complete transection of the sciatic nerve. This injury produced a dramatic reduction of $5-\mathrm{HT}_{1 \mathrm{D}}$-IR in the ipsilateral spinal cord dorsal horn 3 weeks after the surgery (Fig. 5A). Mean optical density of the affected dorsal horn was $10 \%$ of the contralateral side. To determine whether there was a concomitant change in the DRG cell bodies that give rise to these afferents, we double-labeled L5 DRG sections for $5-\mathrm{HT}_{1 \mathrm{D}}$ and for a marker of peptidergic afferents. We monitored CGRP rather than substance $P$ immunoreactivity (IR) as the latter is almost undetectable in DRG after sciatic nerve transection. In contrast to the decreased immunoreactivity of the central terminals, we found persistent $5-\mathrm{HT}_{1 \mathrm{D}}$-IR in peptidergic afferents of the L5 DRG ipsilateral to the nerve injury (Fig. $5 B, C$ ).

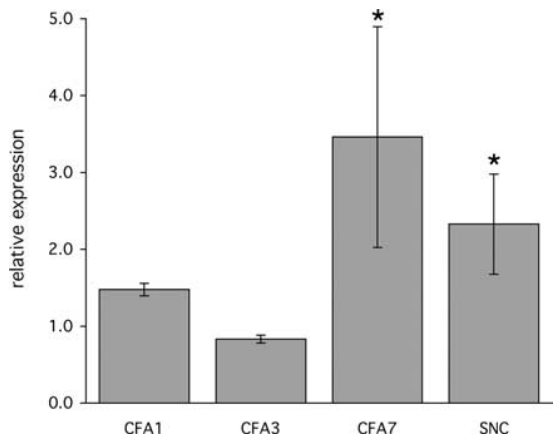

Figure 6. Alteration of 5- $\mathrm{HT}_{1 \mathrm{D}}$ gene expression in chronic models of inflammatory and neuropathic pain. Real-time PCR determination of levels of $5-\mathrm{HT}_{1 \mathrm{D}} \mathrm{mRNA}$ in individual L5 DRG were determined in triplicate and normalized to GAPDH mRNA detected in parallel reactions. Fold changes are expressed as the ratio of levels of cDNA ipsilateral to the injury, compared with the contralateral untreated DRG (see Materials and Methods). Three animals were used for each time point at 1, 3, and $7 \mathrm{~d}$ after unilateral intraplantar CFA injection and $21 \mathrm{~d}$ after unilateral sciatic nerve cut (SNC). ${ }^{*} p<0.05$. Error bars are SEM.

\section{$5-\mathrm{HT}_{1 \mathrm{D}}$ gene expression in models of chronic pain}

Although the very rapid changes in $5-\mathrm{HT}_{1 \mathrm{D}}-\mathrm{IR}$ produced by acute noxious stimulation likely reflect redistribution of the receptor at the central terminal of the primary afferent nociceptor, the changes observed in the setting of persistent injury could also result from changes in $5-\mathrm{HT}_{1 \mathrm{D}}$ gene expression in DRG neurons. To address this possibility, we developed a quantitative real-time PCR assay to determine 5- $\mathrm{HT}_{1 \mathrm{D}}$ mRNA levels in RNA isolated from individual L5 DRGs (Fig. 6A). Normalized to the endogenous GAPDH expression levels, we determined the relative abundance of 5- $\mathrm{HT}_{1 \mathrm{D}}$ mRNA in DRGs ipsilateral to the stimulus compared with the unstimulated contralateral L5 DRG. In the CFA model of chronic inflammatory pain, the ipsilateral $5-\mathrm{HT}_{1 \mathrm{D}}$ mRNA levels were unchanged in the first $2 \mathrm{~d}$ relative to the contralateral side, but at day 3 we found a significant decrease ipsilateral to the inflammation (Fig. 6B). On day 7 the 5- $\mathrm{HT}_{1 \mathrm{D}}$ mRNA levels were elevated compared with the contralateral side. In the sciatic nerve transection model, we found that $5-\mathrm{HT}_{1 \mathrm{D}}$ mRNA levels were also significantly elevated compared with the contralateral side.

\section{Targeting 5- $\mathrm{HT}_{1 \mathrm{D}}$ receptor to $\mathrm{DCVs}$}

The localization of the $5-\mathrm{HT}_{1 \mathrm{D}}$ receptor within peptidergic nociceptive terminals is strikingly similar to that of the DOR, raising the possibility that these two receptors share a common sorting mechanism to DCVs. Guan et al. (2005) recently reported that the third luminal loop of the DOR, but not the analogous region of the $\mu$-opioid receptor (MOR), mediates significant interactions with substance $\mathrm{P}$, and that the loss of substance $\mathrm{P}$ in mice with a deletion of the gene that encodes preprotachykinin (PPTA), the precursor of substance $\mathrm{P}$, is responsible for the greatly reduced levels of DOR-IR in afferent terminals of PPT-A mutant mice.

To determine whether the $5-\mathrm{HT}_{1 \mathrm{D}}$ receptor is regulated in a manner comparable with that of the DOR, we examined DOR and $5-\mathrm{HT}_{\mathrm{ID}}$ receptor-IR in the spinal cords from a line of PPT-A mutant mice generated in our laboratory (Cao et al., 1998). Consistent with the observation of Guan et al. (2005), we found a significant decrease of DOR-IR compared with wild-type littermates (Fig. $7 D, E$ ), but in contrast to the DOR, we found that the pattern and magnitude of $5-\mathrm{HT}_{1 \mathrm{D}}$-IR did not differ in the PPT-A mutant and their wild-type littermates (Fig. $7 B, C$ ). 


\section{Discussion}

We found that a noxious mechanical stimulus produces rapid and complex changes in the magnitude of 5- $\mathrm{HT}_{1 \mathrm{D}}-\mathrm{IR}$ in the spinal cord dorsal horn. In a tissue-injury model of persistent pain, such complex changes in $5-\mathrm{HT}_{1 \mathrm{D}}$-IR in afferent terminals occurred in parallel with changes in $5-\mathrm{HT}_{1 \mathrm{D}}$ receptor gene expression. However, despite there being significantly elevated $5-\mathrm{HT}_{1 \mathrm{D}}$ receptor gene expression in the DRG after sciatic nerve injury, we found a marked reduction of $5-\mathrm{HT}_{1 \mathrm{D}}-\mathrm{IR}$ in afferent terminals, providing evidence for a dissociation between somatic and terminal expression after nerve injury.

\section{Acute activation-induced changes \\ in $5-\mathrm{HT}_{1 \mathrm{D}}$-IR}

The significant and rapid rise in $5-\mathrm{HT}_{1 \mathrm{D}^{-}}$ IR, within $5 \mathrm{~min}$ of noxious mechanical stimulation, most likely reflects synaptic events within the primary afferent terminal rather than the transport of new receptor to the terminal. This view is consistent with studies of McCarson and Goldstein (1990), who showed that noxious stimulation rapidly depletes SP-IR from the spinal cord dorsal horn and that SP levels in perfusates of the spinal cord dorsal horn rise rapidly, presumably after exocytosis of DCVs from peptidergic afferents (McCarson and Goldstein, 1991). Given the close association between substance $\mathrm{P}$ and $5-\mathrm{HT}_{1 \mathrm{D}}$ receptor in primary afferent terminals (Potrebic et al., 2003), one possible explanation for the activity-triggered increase in $5-\mathrm{HT}_{1 \mathrm{D}}-\mathrm{IR}$ is that nociceptor activation redistributes $5-\mathrm{HT}_{1 \mathrm{D}}$ receptorbound vesicles to the plasma membrane,

where the receptor is presumably more efficiently recognized by the antibody. Although we cannot fully explain how an antibody to an intracellular epitope can detect greater levels of $5-\mathrm{HT}_{1 \mathrm{D}}$-IR under these conditions, Cahill et al. (2001) have also reported that immunologically discrete forms of a receptor are detected in DCVs compared with the plasma membrane. A direct confirmation of this interpretation will require ultrastructural or radioligand binding studies of the receptor under these conditions.

The biphasic changes in $5-\mathrm{HT}_{1 \mathrm{D}}$-IR that we observed over time, from minutes to hours after stimulation, could be caused by a variety of synaptic and cellular processes. Internalization and degradation of the receptor within lysosomes could account for the relative loss of $5-\mathrm{HT}_{1 \mathrm{D}}-\mathrm{IR}$ at $30 \mathrm{~min}$. Alternatively, association with $\beta$-arrestin-mediated clathrin-coated pits during vesicular recycling may interfere with the detection of the intracellular epitope to which the antibody was raised. Finally, the subsequent normalization of $5-\mathrm{HT}_{1 \mathrm{D}}$-IR at $90 \mathrm{~min}$ is compatible with the repletion of $5-\mathrm{HT}_{1 \mathrm{D}}$-receptor containing DCVs after axoplasmic transport from cell bodies in the DRG.

This model of 5-HT $\mathrm{HD}_{1 \mathrm{D}}$-receptor delivery to the plasma membrane is directly analogous to the activity-dependent behavior of the DOR (Stewart and Hammond, 1994; Cahill et al., 2001),
$280 \quad 290 \quad 300$

IFVIVWTLVDINRRDPLVVAAL HL IYVIIKALITI PETTFQTVSW HF FFVVSLVL PICRDSCWIHPALFDF

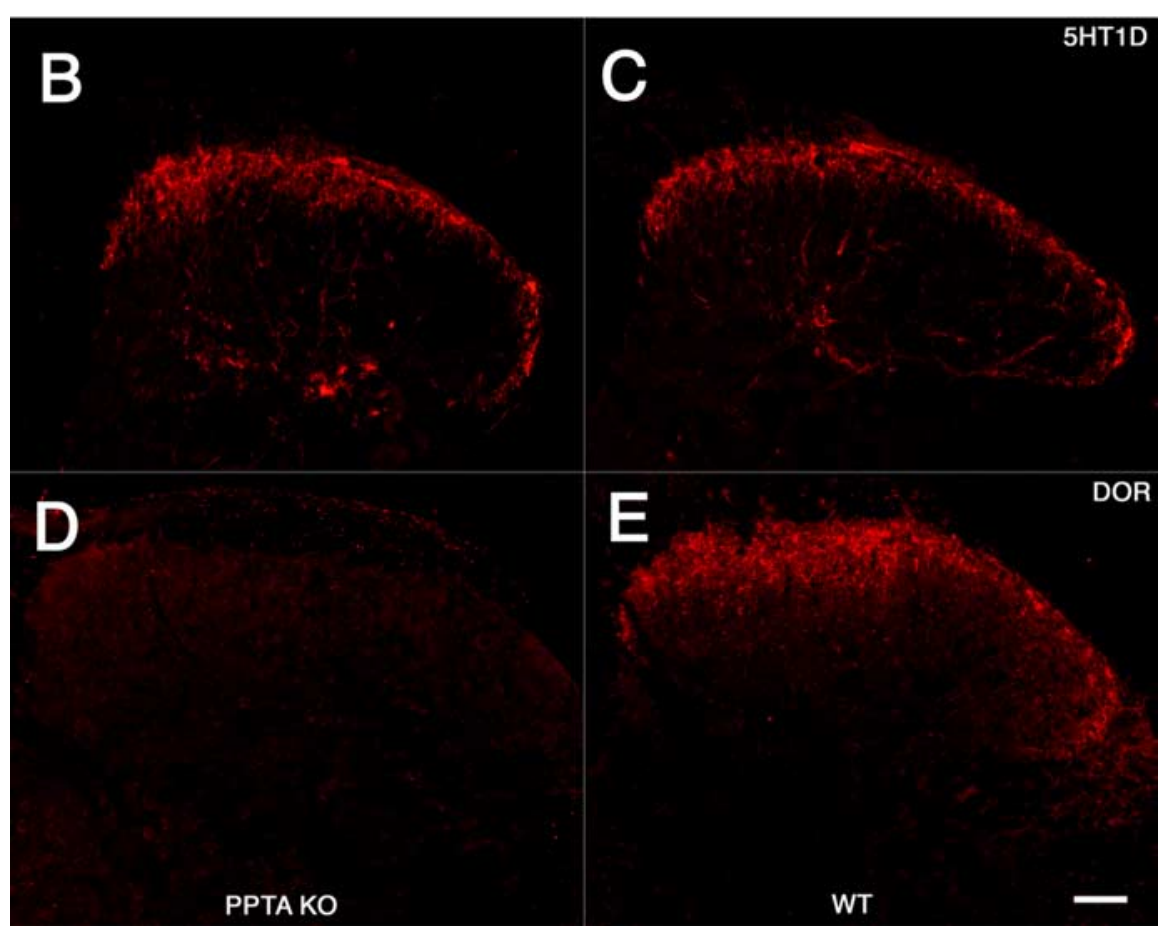

Figure 7. The 5-HT 1 receptor is sorted to DCVs independently of DOR and SP. A, Alignment of the DOR, MOR, and 5-HT receptors in the region of the putative SP-binding domain in the third luminal loop of the DOR, highlighted in yellow. The

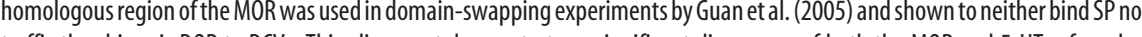
comparable. In contrast, immunostaining of adjacent sections for the DOR shows that it is greatly reduced in PPT-A mutant mice (D) compared with their wild-type littermates $(\boldsymbol{E})$. Scale bar, $40 \mu \mathrm{m}$.

which is also sequestered within DCVs in the spinal cord dorsal horn (Cheng et al., 1995). The DOR redistributes to the cell surface in a stimulation-dependent manner (Bao et al., 2003; Cahill et al., 2003), binds more fluorescently labeled deltorphin after chronic inflammation (Gendron et al., 2006), and stimulates greater agonist-dependent inhibition of intracellular cAMP after stimulation with the inflammatory mediator bradykinin (Patwardhan et al., 2005). Because the DOR also colocalizes with substance $\mathrm{P}$ within DCVs, it is likely that there is a concurrent redistribution of these two receptors to the plasma membrane, both of which would have (auto) inhibitory effects on the activity of the afferent.

\section{Targeting of 5-HT $1 \mathrm{D}$ and DOR receptors to DCVs}

Given the remarkable similarities between the normal distribution of the DOR and the $5-\mathrm{HT}_{1 \mathrm{D}}$ receptors, it is of interest to ask whether they may be cotrafficked from the DRG cell body to the terminal. Using in vitro expression studies, Guan et al. (2005) concluded that substance P interacts directly with the third luminal loop of the DOR, providing a mechanism for DOR trafficking to peptidergic terminals and an explanation for why DOR-IR is greatly reduced in the dorsal horn of mice lacking PPT-A, the gene that encodes the propeptide of substance P (Guan et al., 
2005; Julius and Basbaum, 2005). Our alignment of the putative binding domain of DOR with the corresponding region of the $5-\mathrm{HT}_{1 \mathrm{D}}$ receptor (Fig. $7 \mathrm{~A}$ ) suggests that there is not an analogous interaction between the $5-\mathrm{HT}_{1 \mathrm{D}}$ receptor and substance $\mathrm{P}$, despite their likely colocalization within the same DCVs. In fact, we found a normal pattern of $5-\mathrm{HT}_{1 \mathrm{D}}-\mathrm{IR}$ in the dorsal horn of mice lacking the PPT-A gene, suggesting that this particular mechanism of targeting DOR to DCVs does not represent a generalized process of sorting membrane proteins to this compartment. Moreover, because the $5-\mathrm{HT}_{1 \mathrm{D}}$ receptor is dramatically reduced in the dorsal horn after peripheral nerve injury, our results also emphasize that the downregulation of the DOR by peripheral nerve injury is not necessarily a secondary consequence of the concurrent reduced expression of substance P. The mechanism for the concentration of $5-\mathrm{HT}_{1 \mathrm{D}}$ receptor within DCVs and the subsequent regulation of this receptor at the plasma membrane remains to be determined.

\section{Persistent activation-induced changes in $5-\mathrm{HT}_{1 \mathrm{D}}-\mathrm{IR}$}

With persistent tissue injury (inflammation) we observed a decrease in $5-\mathrm{HT}_{1 \mathrm{D}}-\mathrm{IR}$ on day 3 , a time when tissue swelling and the behavioral effects of CFA-induced hyperalgesia reach their peak (Iadarola et al., 1988). Prolonged nociceptor activation may underlie the relative depletion of the receptor from central terminals, leading to reduced negative feedback on the primary afferent, and enhanced nociceptive processing during this time. These findings parallel 5- $\mathrm{HT}_{1 \mathrm{D}}$-receptor gene expression levels, which declined slightly compared with the contralateral side. Although contralateral effects after inflammation are well known, their relative contribution is likely small compared with the ipsilateral changes in $5-\mathrm{HT}_{1 \mathrm{D}}$-IR under these conditions (Abbadie et al., 1997).

At day 7, when paw edema and the associated hyperalgesia are clearly normalizing, we observed an increase in $5-\mathrm{HT}_{1 \mathrm{D}}-\mathrm{IR}$ in the ipsilateral dorsal horn. The increase in receptor expression does not appear to reflect de novo expression of the receptor by afferents that normally do not express it. Rather, the distribution of $5-\mathrm{HT}_{1 \mathrm{D}}$-IR afferent terminals in the dorsal horn did not change, and DRG neurons with 5-HT 1 -IR continue to colocalize with substance P. Conceivably, the elevated levels of receptor provide greater negative inhibitory feedback on nociceptive afferents during the time of recovery from this type of tissue injury. This result also raises the possibility that triptan administration, which targets the receptor, might have an analgesic effect in these conditions.

\section{Nerve injury-induced depletion of 5- $\mathrm{HT}_{1 \mathrm{D}}-\mathrm{IR}$}

Transection of the sciatic nerve induced a profound loss of $5-\mathrm{HT}_{1 \mathrm{D}}$-IR from the central terminals of the sciatic nerve. It follows that triptans are unlikely to exert a significant regulation of spinal cord nociceptive processing after this kind of nerve injury. Interestingly, the reduction in receptor levels at the nerve terminal is in marked contrast to the upregulation of $5-\mathrm{HT}_{1 \mathrm{D}}$ gene expression in the DRG and the persistence of receptor in the cell body. The loss of 5- $\mathrm{HT}_{1 \mathrm{D}}$-IR in the ipsilateral dorsal horn parallels the loss of DOR-IR after nerve injury (Zhang et al., 1998; Stone et al., 2004), and would thus also have the effect of amplifying pain in the setting of nerve injury.

\section{Are triptans general analgesics?}

If a redistribution of the $5-\mathrm{HT}_{1 \mathrm{D}}$ receptor from intracellular stores to the plasma membrane were also to occur after the activation of trigeminal nociceptors, such as occurs in migraine, then the externalization of the receptor could be the basis for the greater efficacy of triptans in the course of a migraine attack (Burstein et al., 2000). However, because 5- $\mathrm{HT}_{1 \mathrm{D}}$ receptors are present on nociceptors throughout the body, it is surprising that triptans are reportedly effective treatments for only migraine and cluster headache (Ekbom et al., 1995). They are apparently not useful for other primary headache disorders (Antonaci et al., 1998), or other painful disorders of the head (Dao et al., 1995; Harrison et al., 1997), and are not used in the treatment of somatic pain conditions.

Our present results suggest that, under certain experimental conditions, 5- $\mathrm{HT}_{1 \mathrm{D}}$ receptors in regions outside of the trigeminal system are available for triptans to modulate nociceptive processing. Indeed, although triptans have no effect on acute mechanical or thermal nociceptive thresholds (Skingle et al., 1990), Bingham et al. (2001) and our own preliminary studies reveal antinociceptive effects of sumatriptan after inflammatory injury, through an action predominantly at the spinal cord dorsal horn (Nikai et al., 2005).

In contrast to inflammatory pain, the dramatic loss of $5-\mathrm{HT}_{1 \mathrm{D}}$ receptor from afferent terminals after sciatic nerve transection suggests that triptans will have limited utility in the treatment of nerve injury-induced pain. Somewhat paradoxically, Kayser et al. (2002) reported an analgesic effect of triptans after chronic constriction injury of the infraorbital nerve, but saw no analgesic effect after constriction injury of the sciatic nerve. Because there are certainly differences in the central consequences of complete transection versus chronic constriction injury, it will be of great interest to determine whether dorsal horn $5-\mathrm{HT}_{1 \mathrm{D}}$-IR is regulated differently in the latter model of neuropathic pain. Together with other reports that triptans are differentially analgesic for pain after activation of trigeminal afferents, we cannot exclude the possibility of a differential regulation of $5-\mathrm{HT}_{1 \mathrm{D}}$ receptor in the trigeminal nucleus, or the differential activation of descending nociceptive controls by triptans (Cumberbatch et al., 1998; Bartsch et al., 2004).

\section{References}

Abbadie C, Trafton J, Liu H, Mantyh PW, Basbaum AI (1997) Inflammation increases the distribution of dorsal horn neurons that internalize the neurokinin-1 receptor in response to noxious and non-noxious stimulation. J Neurosci 17:8049-8060.

Ahn AH, Basbaum AI (2005) Where do triptans act in the treatment of migraine? Pain 115:1-4.

Antonaci F, Pareja JA, Caminero AB, Sjaastad O (1998) Chronic paroxysmal hemicrania and hemicrania continua: lack of efficacy of sumatriptan. Headache 38:197-200.

Bao L, Jin SX, Zhang C, Wang LH, Xu ZZ, Zhang FX, Wang LC, Ning FS, Cai HJ, Guan JS, Xiao HS, Xu ZQ, He C, Hökfelt T, Zhou Z, Zhang X (2003) Activation of delta opioid receptors induces receptor insertion and neuropeptide secretion. Neuron 37:121-133.

Bartsch T, Knight YE, Goadsby PJ (2004) Activation of 5-HT(1B/1D) receptor in the periaqueductal gray inhibits nociception. Ann Neurol 56:371-381.

Bingham S, Davey PT, Sammons M, Raval P, Overend P, Parsons AA (2001) Inhibition of inflammation-induced thermal hypersensitivity by sumatriptan through activation of 5-HT(1B/1D) receptors. Exp Neurol 167:65-73.

Bolay H, Reuter U, Dunn AK, Huang Z, Boas DA, Moskowitz MA (2002) Intrinsic brain activity triggers trigeminal meningeal afferents in a migraine model. Nat Med 8:136-142.

Burstein R (2001) Deconstructing migraine headache into peripheral and central sensitization. Pain 89:107-110.

Burstein R, Cutrer MF, Yarnitsky D (2000) The development of cutaneous allodynia during a migraine attack: clinical evidence for the sequential recruitment of spinal and supraspinal nociceptive neurons in migraine. Brain 123:1703-1709. 
Buzzi MG, Carter WB, Shimizu T, Heath H, 3rd, Moskowitz MA (1991) Dihydroergotamine and sumatriptan attenuate levels of CGRP in plasma in rat superior sagittal sinus during electrical stimulation of the trigeminal ganglion. Neuropharmacology 30:1193-1200.

Cahill CM, Morinville A, Lee MC, Vincent JP, Collier B, Beaudet A (2001) Prolonged morphine treatment targets $\delta$ opioid receptors to neuronal plasma membranes and enhances $\delta$-mediated antinociception. J Neurosci 21:7598-7607.

Cahill CM, Morinville A, Hoffert C, O’Donnell D, Beaudet A (2003) Upregulation and trafficking of delta opioid receptor in a model of chronic inflammation: implications for pain control. Pain 101:199-208.

Cao YQ, Mantyh PW, Carlson EJ, Gillespie AM, Epstein CJ, Basbaum AI (1998) Primary afferent tachykinins are required to experience moderate to intense pain. Nature 392:390-394.

Cheng PY, Svingos AL, Wang H, Clarke CL, Jenab S, Beczkowska IW, Inturrisi CE, Pickel VM (1995) Ultrastructural immunolabeling shows prominent presynaptic vesicular localization of $\delta$-opioid receptor within both enkephalin- and nonenkephalin-containing axon terminals in the superficial layers of the rat cervical spinal cord. J Neurosci 15:5976-5988.

Cumberbatch MJ, Hill RG, Hargreaves RJ (1998) Differential effects of the $5-\mathrm{HT} 1 \mathrm{~B} / 1 \mathrm{D}$ receptor agonist naratriptan on trigeminal versus spinal nociceptive responses. Cephalalgia 18:659-663.

Dao TT, Lund JP, Remillard G, Lavigne GJ (1995) Is myofascial pain of the temporal muscles relieved by oral sumatriptan? A cross-over pilot study. Pain 62:241-244.

Ekbom K, Krabbe A, Micieli G, Prusinski A, Cole JA, Pilgrim AJ, Noronha D, Micieli G (1995) Cluster headache attacks treated for up to three months with subcutaneous sumatriptan $(6 \mathrm{mg})$. Sumatriptan cluster headache long-term study group. Cephalalgia 15:230-236.

Gendron L, Lucido AL, Mennicken F, O’Donnell D, Vincent JP, Stroh T, Beaudet A (2006) Morphine and pain-related stimuli enhance cell surface availability of somatic delta-opioid receptors in rat dorsal root ganglia. J Neurosci 26:953-962.

Goadsby PJ, Akerman S, Storer RJ (2001) Evidence for postjunctional serotonin (5-HT1) receptors in the trigeminocervical complex. Ann Neurol 50:804-807.

Goadsby PJ, Lipton RB, Ferrari MD (2002) Migraine-current understanding and treatment. N Engl J Med 346:257-270.

Guan JS, Xu ZZ, Gao H, He SQ, Ma GQ, Sun T, Wang LH, Zhang ZN, Lena I, Kitchen I, Elde R, Zimmer A, He C, Pei G, Bao L, Zhang X (2005) Interaction with vesicle luminal protachykinin regulates surface expression of delta-opioid receptors and opioid analgesia. Cell 122:619-631.

Harrison SD, Balawi SA, Feinmann C, Harris M (1997) Atypical facial pain: a double-blind placebo-controlled crossover pilot study of subcutaneous sumatriptan. Eur Neuropsychopharmacol 7:83-88.

Iadarola MJ, Brady LS, Draisci G, Dubner R (1988) Enhancement of dynorphin gene expression in spinal cord following experimental inflammation: stimulus specificity, behavioral parameters and opioid receptor binding. Pain 35:313-326.

Jennings EA, Ryan RM, Christie MJ (2004) Effects of sumatriptan on rat medullary dorsal horn neurons. Pain 111:30-37.

Julius D, Basbaum AI (2005) A neuropeptide courier for delta-opioid receptors? Cell 122:496-498.

Kaube H, Hoskin KL, Goadsby PJ (1993) Inhibition by sumatriptan of central trigeminal neurones only after blood-brain barrier disruption. Br J Pharmacol 109:788-792.

Kayser V, Aubel B, Hamon M, Bourgoin S (2002) The antimigraine $5-\mathrm{HT}(1 \mathrm{~B} / 1 \mathrm{D})$ receptor agonists, sumatriptan, zolmitriptan and dihydro- ergotamine, attenuate pain-related behaviour in a rat model of trigeminal neuropathic pain. Br J Pharmacol 137:1287-1297.

Levy D, Jakubowski M, Burstein R (2004) Disruption of communication between peripheral and central trigeminovascular neurons mediates the antimigraine action of 5-HT 1B/1D receptor agonists. Proc Natl Acad Sci USA 101:4274-4279.

Markowitz S, Saito K, Moskowitz MA (1987) Neurogenically mediated leakage of plasma protein occurs from blood vessels in dura mater but not brain. J Neurosci 7:4129-4136.

McCarson KE, Goldstein BD (1990) Time course of the alteration in dorsal horn substance P levels following formalin: blockade by naloxone. Pain 41:95-100.

McCarson KE, Goldstein BD (1991) Release of substance P into the superficial dorsal horn following nociceptive activation of the hindpaw of the rat. Brain Res 568:109-115.

Moskowitz MA (1993) Neurogenic inflammation in the pathophysiology and treatment of migraine. Neurology 43:S16-20.

Nikai T, Basbaum AI, Ahn AH (2005) Sumatriptan regulates nontrigeminal pain in the setting of inflammation. Soc Neurosci Abstr 31:511.28.

Patwardhan AM, Berg KA, Akopain AN, Jeske NA, Gamper N, Clarke WP, Hargreaves KM (2005) Bradykinin-induced functional competence and trafficking of the $\delta$-opioid receptor in trigeminal nociceptors. J Neurosci 25:8825-8832.

Potrebic S, Ahn AH, Skinner K, Fields HL, Basbaum AI (2003) Peptidergic nociceptors of both trigeminal and dorsal root ganglia express serotonin $1 \mathrm{D}$ receptors: implications for the selective antimigraine action of triptans. J Neurosci 23:10988-10997.

Shepheard SL, Williamson DJ, Williams J, Hill RG, Hargreaves RJ (1995) Comparison of the effects of sumatriptan and the NK1 antagonist CP99,994 on plasma extravasation in Dura mater and c-fos mRNA expression in trigeminal nucleus caudalis of rats. Neuropharmacology 34:255-261.

Skingle M, Birch PJ, Leighton GE, Humphrey PP (1990) Lack of antinociceptive activity of sumatriptan in rodents. Cephalalgia 10:207-212.

Stewart PE, Hammond DL (1994) Activation of spinal delta-1 or delta-2 opioid receptors reduces carrageenan-induced hyperalgesia in the rat J Pharmacol Exp Ther 268:701-708.

Stone LS, Vulchanova L, Riedl MS, Williams FG, Wilcox GL, Elde R (2004) Effects of peripheral nerve injury on delta opioid receptor (DOR) immunoreactivity in the rat spinal cord. Neurosci Lett 361:208-211.

Storer RJ, Akerman S, Goadsby PJ (2004) Calcitonin gene-related peptide (CGRP) modulates nociceptive trigeminovascular transmission in the cat. Br J Pharmacol 142:1171-1181.

Strassman AM, Raymond SA, Burstein R (1996) Sensitization of meningeal sensory neurons and the origin of headaches. Nature 384:560-564.

Wong HC, Tache Y, Lloyd KC, Yang H, Sternini C, Holzer P, Walsh JH (1993) Monoclonal antibody to rat alpha-CGRP: production, characterization, and in vivo immunoneutralization activity. Hybridoma 12:93-106.

Zagami AS, Goadsby PJ, Edvinsson L (1990) Stimulation of the superior sagittal sinus in the cat causes release of vasoactive peptides. Neuropeptides 16:69-75

Zhang X, Bao L, Arvidsson U, Elde R, Hökfelt T (1998) Localization and regulation of the delta-opioid receptor in dorsal root ganglia and spinal cord of the rat and monkey: evidence for association with the membrane of large dense-core vesicles. Neuroscience 82:1225-1242. 